Journal of Humanities and Social Sciences Studies (JHSSS)

ISSN: 2663-7197

DOI: $10.32996 /$ jhsss

Journal homepage: https://al-kindipublisher.com/index.php/jhsss

\title{
Problems of the Farmers in Marketing Paddy in Cauvery Delta Zone, Tamilnadu
}

S. KARTHICK ${ }^{1}$ and Dr.R. SAMINATHAN ${ }^{2}$

${ }^{1}$ Part time Research Scholar, Bharathidasan University, Trichy

${ }^{2}$ Head of Department of Commerce, Govt. Arts and Science College, Lalgudi

Corresponding Author: S. KARTHICK, E-mail: drsbsm@rediffmail.com

ARTICLE INFORMATION

Received: October 21, 2020

Accepted: November 18, 2020

Volume: 2

Issue: 6

DOI: 10.32996/jhsss.2020.2.6.18 KEYWORDS

Farmer administration, farmer gracious, economy, agriculture, profit, Government

\section{ABSTRACT}

Indian economy is essentially a rural economy. The very presence of monetary exercises of the whole individuals is bound up with the state and soundness of this area. In India, around $70 \%$ of individuals are occupied with horticultural interests and around $50 \%$ of the public pay starts from agribusiness. Henceforth the degree of effectiveness and profitability in horticulture pretty much decides the productivity of Indian economy. In India, individuals and their whole entirety are such a great amount of bound up with the fortunes of horticulture that the movement of life and the example of exercises do close to reflect all that occurs in this area. Since farming is the benefactor of the biggest measure of merchandise and enterprises to the improvement of the nation, it gets fundamental and dependable with respect to the Government to manage and control the promoting arrangement of Agricultural produce. Horticultural promoting in India is plagued with numerous deformities. "The rancher, when all is said in done, sells his produce at a troublesome spot and at an ominous time, and generally gets entirely horrible terms." So, in such conditions, it isn't unexpected to find that the horticultural makers as a class are being abused by the buyers. There are several problems that play a role in the marketing of paddy in the cavery delta zone in tamilnadu like labour, transportation etc.,. The study adopted survey method to examine the problems of marketing with 320 farmers. The study concluded that the goal of central as well as state Government to advance a sound food strategy through a sound advertising framework can be accomplished by taking out the inborn deformities in paddy promoting and makes the obtainment framework farmers.

\section{Introduction}

Paddy, being the significant food grain, needs to go through an excessive number of go betweens, for example, commission operators, wholesalers, mill operators cum wholesalers, retailers in the chain of dissemination. Such an excessive number of go betweens take lion portion of benefit and therefore the cost goes up strangely. Consequently, as a measure to try not to profiteer by the agents, our Government will undoubtedly advance a sound food strategy of monitoring the cost consistently and keeping up sufficient stock situation to meet the rice necessities of individuals under open dissemination framework. Additionally, the Government will undoubtedly impact a sound advertising framework to empower the makers to get reasonable cost for their produce by dispensing with the innate deformities pervasive in agrarian promoting, for example, absence of associations, constrained deals, presence of pointless agents, variety of market charges, assortment of loads and measures and acts of neglect of business sectors. In this way, it gets critical to learn about restraining infrastructure obtainment framework and its accomplishment in accomplishing its targets.

\section{Statement of the Problem}

The situation of horticultural promoting in India is despicable. The Indian rancher is extremely poor, unskilled and oblivious. The twin goals of the Government that guaranteeing MSP to the ranchers and furthermore guaranteeing accessibility of food

\footnotetext{
K C AL-KINDI CENTER

$\mathbf{R}$ D FOR RESEARCH AND $\mathbf{R} \mathbf{D}$ DEVELOPMENT
} Published by Al-Kindi Center for Research and Development. Copyright (c) the author(s). This is an open access article Your gateway to world-class research 
grains to the more vulnerable areas at reasonable costs were crushed because of the presence of brokers, acts of neglect and so on, even now in the acquirement arrangement of the Government. Henceforth, an examination has been proposed to investigate the exercises of the Government in paddy obtainment and to survey the issues of paddy makers in that association.

\section{Objectives of the Study}

The objectives of the study are:

a. To analyse the various problems of agricultural marketing of paddy ;

b. To examine the production and marketing problems of paddy growers in Cauvery delta.

\section{Methodology}

The study is descriptive in nature. Survey method was adopted to carry out the objectives of the study. Both primary and secondary data were used in the study.

\subsection{Data Collection}

Secondary data were collected from a wide spectrum of sources including Websites of various organizations. The primary data were collected from the farmers of the district by conducting sample surveys using structured, pre-tested interview schedules, adopting stratified random sampling models.

\subsection{Data collection tool}

A well-structured interview schedule was administered in this study to elicit information from the sample farmers.

\subsection{Population of the study}

The population of the study constitutes the total number of farmers in the Cauvery delta zone.

\subsection{Sources of data}

Cauvery delta zone contains seven areas. Of these, solitary four areas were taken up for the examination. There are 98 Primary Agricultural Co-employable Banks (PACB) in these four districts. A rundown of 98 PACBs and their addresses were gotten from KCCB Central Office, which filled in as the wellspring of data needed for the current investigation. Essentially a rundown of DPCs working in the investigation zone was gotten from the TNCSC Ltd., of each region and the equivalent was utilized as the source to choose test Bill clerks.

\subsection{Samples from farmers}

From the rundown of PACBs, 20 were chosen aimlessly. Registers of Members of the PACBs were utilized for choosing individuals. With the assistance of the rundown of individuals, non-individuals were recognized and chosen. Of these 20 PACBs, 4 from each region were chosen on an arbitrary premise. There are four classifications of ranchers specifically Big, Medium, Small and Marginal ranchers in the examination zone. Accordingly, an aggregate of 320 ranchers, 4 ranchers of every classification from each PACB were chosen on irregular premise. Among the ranchers almost $20 \%$ are nonmembers of the PACBs. Accordingly, to incorporate them likewise, 80 ranchers, 16 ranchers from each region (4 every one of the 4 classes) were additionally chosen aimlessly. Consequently, the complete number of Sample ranchers of the examination was 400-320 from PACB individuals and 80 from PACB nonmembers.

\subsection{Analysis of Data}

The data collected were classified, tabulated, analysed and interpreted with the assist of applicable statistical tools making use of Statistical Package for Social sciences (SPSS).

\section{Hypotheses}

1) $\mathrm{H}_{1}$ : There is a significant relationship between the amount of investment and their overall dimensions of marketing problems faced by paddy growers.

$\mathrm{H}_{0}$ : There is no significant relationship between the amount of investment and their overall dimensions of marketing problems faced by paddy growers.

2) $\mathrm{H}_{1}$ : There is a significant difference between the age of the farmers and their marketing dimensions of business problems.

$\mathrm{H}_{0}$ : There is no significant difference between the age of the farmers and their marketing dimensions of business problems. 


\section{Indian scenario of Procurement of Paddy}

The Government strategy of acquirement of food grains has the wide goals of guaranteeing Minimum Support Price (MSP) to the ranchers and furthermore guaranteeing accessibility of food grains to the more fragile areas at reasonable costs. It likewise guarantees viable market mediation accordingly holding the costs under check and furthermore adding to the general food security of the nation. The Food Corporation of India (FCI), the nodal focal office of the Government of India, alongside other State Agencies embraces acquirement of wheat, paddy and coarse grains under value uphold plan and rice under legal duty conspire. The acquisition under Price Support is taken up chiefly to guarantee gainful costs to the ranchers for their produce which functions as a motivating force for accomplishing better creation.

Prior to the collect during each Rabi/Kharif Crop season, the Government of India reports the MSP for acquisition based on the suggestion of the Commission of Agricultural Costs and Prices (CACP) which alongside different components thinks about the expense of different agrarian information sources and the sensible edge for the ranchers for their produce. To encourage obtainment of food grains, $\mathrm{FCl}$ and different State Agencies in conference with the State Government set up countless buy communities at different towns and central issues. The quantity of focuses and their areas are chosen by the State Governments, in light of different boundaries, in order to amplify the MSP tasks. For example, for acquiring Wheat and Rice, in excess of 24000 acquisition focuses were worked for each yield during 2019-20.

Such broad and viable value uphold tasks have brought about supporting the pay of ranchers over a period and in giving the necessary force to higher interest in agribusiness area for improved profitability. Whatever stocks, which are brought to the buy communities falling inside the determinations of the Government of India, are bought at the fixed help cost. On the off chance that the ranchers improve than the help cost from different purchasers, for example, brokers, mill operators and so on, the ranchers are allowed to offer their produce to them. $\mathrm{FCl}$ and the State Government or its organizations guarantee that the ranchers are not constrained to sell their produce underneath help cost.

\section{Tamil Nadu Scenario of Procurement of Paddy}

The Tamil Nadu Civil Supplies Corporation Ltd., (TNCSC Ltd.,) made a start in the field of neighborhood acquisition of paddy and rice from Samba 1973 through toll and direct buys. There are two primary seasons for obtaining paddy in Tamil Nadu in particular Kuruvai (from first October to fifteenth December) and Samba (from sixteenth December to 31st July). The obtainment activity which started from Samba 1973 proceeded with from there on under different frameworks like Monopoly acquisition, Parallel acquirement, Levy framework and Compulsory acquirement upto 30-09-2002 either exclusively or in mix contingent on the conditions at different purpose of time. From 01-10-2002 Government of Tamil Nadu has received Decentralized System of obtainment according to the MSP and uniform detail fixed by the Government of India. The TNCSC Ltd., has become the sole organization of obtainment for the benefit of Food Corporation of India. The arrangement of acquisition in Tamil Nadu was made carefully by the Corporation from the ranchers without including any delegates by opening bigger number of Direct Purchase Centers (DPCS) in different towns with the considerable amount of acquirement actually used to originate from the Cauvery delta territory. The acquirement in other potential locale is likewise being energized by the Corporation and the State Government. The Corporation is having 23 Modern Rice Mills generally packed in the Cauvery delta zones and the paddy obtained is hulled through these factories and furthermore through the private Hulling Agents enlisted by the Corporation. The uniquely processed rice is changed against the focal pool allocation made to the State by Government of India. 
Table 1: Karl Pearson Test between the amount of investment and their overall Dimensions of marketing problems faced by paddy growers

\begin{tabular}{|c|c|c|c|c|}
\hline $\begin{array}{l}\text { Amount invested in a } \\
\text { year for Agriculture }\end{array}$ & Mean & $\begin{array}{c}\text { Std. } \\
\text { Deviation }\end{array}$ & $\begin{array}{l}\text { Pearson } \\
\text { R Value }\end{array}$ & $\begin{array}{l}\text { Statistical } \\
\text { significant }\end{array}$ \\
\hline Labour problems & 14.55 & 1.353 & -.065 & $\begin{array}{c}.167>0.05 \\
\text { Not } \\
\text { significant }\end{array}$ \\
\hline $\begin{array}{l}\text { Raw Material Related } \\
\text { Problems }\end{array}$ & 14.80 & 1.367 & .009 & $\begin{array}{c}.849>0.05 \\
\text { Not } \\
\text { significant }\end{array}$ \\
\hline Technological and Quality & 14.62 & 1.245 & .004 & $\begin{array}{c}.936>0.05 \\
\text { Not } \\
\text { significant }\end{array}$ \\
\hline Production cultivation & 14.57 & 1.254 & .047 & $\begin{array}{c}.319>0.05 \\
\text { Not } \\
\text { significant }\end{array}$ \\
\hline Inter firm Competition & 14.92 & 1.475 & .028 & $\begin{array}{c}.547>0.05 \\
\text { Not } \\
\text { significant }\end{array}$ \\
\hline Marketing related problem & 14.88 & 1.474 & -.009 & $\begin{array}{c}.846>0.05 \\
\text { Not } \\
\text { significant }\end{array}$ \\
\hline Finance related problem & 14.85 & 1.353 & -.011 & $\begin{array}{c}.858>0.05 \\
\text { Not } \\
\text { significant }\end{array}$ \\
\hline Government Policy & 14.20 & 1.166 & -.019 & $\begin{array}{c}.692>0.05 \\
\text { Not } \\
\text { significant }\end{array}$ \\
\hline Business Environment & 14.50 & 1.224 & .036 & $\begin{array}{c}.443>0.05 \\
\text { Not } \\
\text { significant }\end{array}$ \\
\hline Over all Problems & 71.70 & 6.203 & .032 & $\begin{array}{c}.502>0.05 \\
\text { Not } \\
\text { significant }\end{array}$ \\
\hline
\end{tabular}

The determined worth is $\mathrm{R}=0.32$; the determined worth is more noteworthy than the table worth (0.502 >0.05.) So research speculation is dismissed and the invalid theory is acknowledged. It is discovered that there is a critical connection between the measure of venture and their general elements of showcasing issues looked by paddy cultivators. Issues looked by the ranchers may contrast as indicated by their speculation models. The scientist examined through Karl Pearson test and found that there is no huge connection between the measure of venture and their general elements of showcasing issues looked by paddy cultivators.

Table 2: Kruskal-Wallis test difference age of the farmers and their Marketing dimensions of Business Problems

\begin{tabular}{|l|l|l|l|l|}
\hline \multicolumn{1}{|c|}{ Age } & Mean Rank & Chi-square & Df & Statistical Inference \\
\hline Marketing related Problems & & & & \\
\hline Below 30 years (61) & 220.20 & 0.415 & 3 & $.937<0.05$, Significant \\
\hline $31-40$ years (67) & & & & \\
\hline 41-50 years (382) & 216.57 & & & \\
\hline Above 51 years (140) & 226.51 & & & \\
\hline
\end{tabular}

The determined worth is $\mathrm{K}=0.364$; the determined worth is not exactly the table worth $(0.364<0.05$.) So research theory is acknowledged and the invalid speculation is dismissed. It is discovered that there is a critical contrast between the age of the ranchers and their general components of business issues. Age is the central point which impacts ranchers' business. 
Consequently, the scientist dissected through Kruskal-Wallis test the distinction between the age of the ranchers and their general components of business issues.

\section{Conclusion}

At last, the TNCSC Ltd. as the organization of the Government has assumed a critical function in the paddy acquisition tasks and in this manner for the government assistance of paddy makers in Cauvery delta locale. Simultaneously the exhibition of the TNCSC Ltd. Has its own personal inadequacy in specific perspectives. These deficiencies are to be over come through reasonable activities. The authorities associated with the acquisition activity ought to be genuine, cheerful and legit to the paddy makers to win their certainty. At that point just, the goal of our Government to advance a sound food strategy through a sound advertising framework can be accomplished by taking out the inborn deformities in paddy promoting and makes the obtainment framework a rancher - well-disposed one.

\section{References}

[1] Agarval A.N. (2002). Indian Economy-Problems of Development and Planning. Wishwa Prakashan, New Delhi,346348.

[2] Anitha J. (2016). An Economic Study of Paddy Cultivation in Kanyakumari District. International Journal of Research, 4 (10), 63-69.

[3] Prakash C. (2012). Problems and expectations of the farmers in marketing paddy in Tiruvarur district, Tamilnadu", Asian Journal of Management Research, 3(1), 253-263.

[4] Sreenivasa, P, D \& Narayana, T. (2018). A study on Marketing Problems of Paddy and Bengal Gram Farmers with special reference to Kurnool District, Andhra Pradesh. International Journal of Management, Technology And Engineering, 8 (VI), 579-588.

[5] Meena, K \& RaviGopal, S. (2017) "Status Problem and Prospects of Chickpea Production in Bihar: A Situation Analysis," International Journal of Current Microbiology and Applied Sciences, 6(8), 3555-3563. 